JOURNAL OF PLANT NUTRITION, 25(7), 1429-1442 (2002)

\title{
RELATIONSHIP BETWEEN AMMONIUM AND NITRATE IN WHEAT PLANT TISSUE AND ESTIMATED NITROGEN LOSS
}

\author{
D. A. Cossey, W. E. Thomason, R. W. Mullen, \\ K. J. Wynn, C. W. Woolfolk, G. V. Johnson, and \\ W. R. Raun* \\ Department of Plant and Soil Sciences, 165 Agricultural \\ Hall, Oklahoma State University, Stillwater OK, 74078
}

\begin{abstract}
Nitrogen $(\mathrm{N})$ is one of the most important elements in the nutrition of higher plants and one of the most costly inputs in the production of winter wheat in the Great Plains. Nitrogen ranks second only to precipitation as the most frequent yield limiting factor, and even when $\mathrm{N}$ is not the yield limiting factor, wheat is less than $50 \%$ efficient at utilizing applied $\mathrm{N}$ fertilizer. If $\mathrm{N}$ supplied to the crop is not utilized efficiently, it may be lost from the cropping system to the surrounding environment. The objective of this study was to evaluate the relationship between $\mathrm{NH}_{4}-\mathrm{N}$ and $\mathrm{NO}_{3}-\mathrm{N}$ in wheat tissue and estimated plant $\mathrm{N}$ loss. Two experimental sites for this study were selected as subplots located within existing plots in two long-term winter wheat experiments at Stillwater (experiment 222) and Lahoma (experiment 502), Oklahoma. Wheat forage samples were collected at
\end{abstract}

*Corresponding author. E-mail: wrr@mail.pss.okstate.edu

1429 
Feekes growth stage five (leaf sheath strongly erected) and Feekes growth stage 10.5 (flowering complete to top of ear). Samples were dried, ground, and analyzed for total $\mathrm{N}, \mathrm{NH}_{4}-\mathrm{N}$, and $\mathrm{NO}_{3}-\mathrm{N}$. The relationship between total $\mathrm{N}, \mathrm{NH}_{4}-\mathrm{N}$, and $\mathrm{NO}_{3}-\mathrm{N}$ at both growth stages and estimated plant nitrogen loss (plant $\mathrm{N}$ uptake at flowering minus total $\mathrm{N}$ uptake in the grain plus straw) were evaluated. No relationship was found to exist between forage $\mathrm{NH}_{4}-\mathrm{N}$ and $\mathrm{NO}_{3}-\mathrm{N}$ and estimated plant $\mathrm{N}$ loss. Due to cool and moist climatic conditions during late spring in both years, estimated $\mathrm{N}$ losses were small from anthesis to maturity using the method described. Plant tissue $\mathrm{NO}_{3}-\mathrm{N}$ at Feekes five was correlated with total $\mathrm{N}$ accumulation in the plant at flowering and with grain $\mathrm{N}$ uptake at experiment 502 in both years.

\section{INTRODUCTION}

It is important to understand losses of nitrogen that occur within the soilplant system, and how these losses may affect nitrogen use efficiency. Denitrification, volatilization from the soil surface, and leaching are potential losses of $\mathrm{N}$. Denitrification is the conversion of nitrate nitrogen $\left(\mathrm{NO}_{3}-\mathrm{N}\right)$ to gaseous forms such as $\mathrm{N}_{2} \mathrm{O}, \mathrm{NO}$, and $\mathrm{N}_{2}$. This process occurs in anaerobic conditions, usually at $\mathrm{pH}<6.0$. In many fertilizer recovery studies, denitrification is often cited as the most significant loss of $\mathrm{N}$. Nitrogen losses due to denitrification of applied fertilizer have been reported as ranging from $9.5 \%{ }^{[1]}$ to $22 \%{ }^{[2]}$ Another potential loss is ammonia $\left(\mathrm{NH}_{3}\right)$ volatilization from the soil surface. Fertilizer N (especially urea) added to a soil with a $\mathrm{pH}$ greater than 7.0 may result in $\mathrm{NH}_{3}$ volatilization and further loss of fertilizer $\mathrm{N}$. Losses of $55-65 \%$ of applied urea have been reported. ${ }^{[3,4]}$ This can be significant under environmental conditions such as low moisture, high wind velocity, and high soil $\mathrm{pH}$. Nitrogen leaching is the process whereby $\mathrm{NO}_{3}-\mathrm{N}$ is translocated by percolation of water through the soil profile, which can lead to groundwater contamination. One study reported that $113 \mathrm{~kg} \mathrm{ha}^{-1}$ of $\mathrm{NO}_{3}-\mathrm{N}$ leached below the root zone when two consecutive bean crops were grown. ${ }^{[5]}$

Tissue analysis has been used to determine nutrient deficiencies in-season and to establish rates of subsequent additions of $\mathrm{N}$ fertilizer. It may be possible to use tissue tests at certain stages of growth to estimate the amount of $\mathrm{N}$ being volatilized from the crop canopy. The relationship between ammonium and nitrate in wheat tissue has not been evaluated as a tool to predict estimated gaseous $\mathrm{N}$ loss in winter wheat. Understanding gaseous $\mathrm{N}$ loss may be a key to increasing the efficient use of $\mathrm{N}$ fertilizers applied to cropping systems. Harper et al., ${ }^{[6]}$ in an $\mathrm{N}$ 
cycling study, concluded that approximately $11 \%$ of applied $\mathrm{N}$ was lost in a 20 -day period following fertilization from the soil-plant system. The plant loss was attributed to the overloading of plant $\mathrm{N}$ as $\mathrm{NH}_{4}{ }^{+}$. They considered additional losses of $\mathrm{N}(9.8 \%)$ from the plants between anthesis and maturity. This loss was due almost entirely to plant senescence and inefficient redistribution of $\mathrm{N}$ within the plant. Eleven percent of the potential $\mathrm{N}$ available for redistribution from the stems and leaves was lost as volatile $\mathrm{NH}_{3}$. The high $\mathrm{N}$ (and therefore, increased $\mathrm{NH}_{4}^{+}$) content of the plants lends itself to $\mathrm{NH}_{3}$ volatilization from the plant to the atmosphere. Francis et al. ${ }^{[7]}$ in a corn (Zea maize L.) study found that $\mathrm{N}$ losses from aboveground biomass in a hybrid variety ranged from 45 to $81 \mathrm{~kg} \mathrm{Nha}^{-1}$. Also, they reported that 52 to $73 \%$ of the unaccounted for fertilizer in ${ }^{15} \mathrm{~N}$ balance studies could be attributed to plant $\mathrm{N}$ loss. They also stated that in the past, studies have listed denitrification as a major sink for gaseous loss of N. Estimates of $\mathrm{N}$ loss via denitrification and leaching might have been less if plant $\mathrm{N}$ volatilization had been considered. Papakosta and Gagianas ${ }^{[8]}$ stated that $\mathrm{N}$ loss from anthesis to maturity depends on the plant $\mathrm{N}$ content at anthesis. When $\mathrm{N}$ content was high at anthesis $\left(>200 \mathrm{~kg} \mathrm{ha}^{-1}\right), \mathrm{N}$ losses were inevitable even when yields were high. When $\mathrm{N}$ content was lower $\left(150 \mathrm{~kg} \mathrm{ha}^{-1}\right)$ at anthesis, $\mathrm{N}$ losses were not observed. Between these $\mathrm{N}$ contents, $\mathrm{N}$ loss was highly correlated with yield, where high yields prevented $\mathrm{N}$ loss and low yields caused a net loss of $\mathrm{N}$. Daigger et al. (1976) studying $\mathrm{N}$ content in wheat noted that the percent $\mathrm{N}$ in plant tissue did not change during a 23-day period preceding maturity. He found, though, that the period between anthesis and maturity netted a total loss of $30 \%$ of the applied $\mathrm{N}$, and losses of $\mathrm{N}$ increased with increasing $\mathrm{N}$ applied. The $\mathrm{N}$ loss accounted for 26 , 28 , and $41 \%$ of the anthesis $\mathrm{N}$ when 0,67 , and $133 \mathrm{~kg}$ of $\mathrm{Nha}^{-1}$ were applied, respectively. In the above-cited studies the major components of gaseous $\mathrm{N}$ loss seem to be the amount of $\mathrm{N}$ supplied to the plant and, therefore, the plant content of $\mathrm{N}$ at later stages of growth. Because of this, it is important to understand the processes controlling $\mathrm{N}$ uptake and assimilation within the growing wheat plants and redistribution of supplied $\mathrm{N}$, especially at later stages of growth.

Grain production is greatly affected by $\mathrm{NH}_{4}{ }^{+}$and $\mathrm{NO}_{3}{ }^{-}$nutrition. Silberbush and Lips ${ }^{[10]}$ found that the number of tillers per plant was correlated with dry matter yield. The number of tillers also increased with nitrogen concentration and with $\mathrm{NH}_{4}{ }^{+} / \mathrm{NO}_{3}{ }^{-}$ratio fed to plants. Mean grain weight and number of grains per plant were negatively correlated with $\mathrm{NH}_{4}{ }^{+} / \mathrm{NO}_{3}{ }^{-}$ratio fed to plants. They concluded that plants receiving high $\mathrm{NH}_{4}{ }^{+}$concentrations are stimulated to invest most of their carbohydrate reserves on new tiller formation. Nitrate-fed plants, on the other hand, invest the bulk of the carbohydrates in grain production. In a study by Martin del Molino, ${ }^{[11]}$ grain protein increased linearly with grain yield and aboveground plant dry weight at anthesis. Grain yield also increased linearly with leaf $\mathrm{N}$ content at anthesis. The study showed, however, that grain protein was more closely related to the aboveground dry weight at anthesis multiplied by the level of 
$\mathrm{N}$ in the two upper most leaves, than either of the components considered separately. Leaf $\mathrm{N}$ concentration at anthesis had less of an effect on grain protein and more effect on the production of biomass. Raun and Westerman ${ }^{[12]}$ found that crown and leaf $\mathrm{NO}_{3}{ }^{-}$was correlated with yield when sampled at Feekes growth stages foure and five. A linear relationship was established between leaf $\mathrm{NO}_{3}{ }^{-}$ content and $\mathrm{N}$ rate at Feekes 5. Samples taken at Feekes 7 and 10 did not correlate well with yield. Gregory et al., ${ }^{[13]}$ in a nutrient study found that even when there was limited uptake of $\mathrm{N}$ after anthesis, the grain continued to grow and substantial amounts of $\mathrm{N}$ was translocated from the leaves and stems. He stated that 23 to $52 \%$ of the final amount of $\mathrm{N}$ contained in the grain was taken up after anthesis. He concluded that amounts of $\mathrm{N}$ and moisture in the soil played a major role in the amount of $\mathrm{N}$ translocated from other parts of the plants.

\section{MATERIALS AND METHODS}

Two experimental sites were selected as subplots located within existing plots in two long-term winter wheat experiments at Stillwater (experiment 222) and Lahoma (experiment 502), Oklahoma. Fixed preplant nitrogen rates have been applied annually since 1969 and 1970 in experiments 222 and 502, respectively. Both experiments employ randomized complete block designs with four replications. Plots were $6.1 \times 18.3 \mathrm{~m}$ and $4.9 \times 18.3 \mathrm{~m}$ at experiments 222 and 502, respectively. Nitrogen rates were $0,45,90$, and $134 \mathrm{~kg} \mathrm{ha}^{-1} \mathrm{yr}^{-1}$ at Stillwater and $0,45,67,90$, and $112 \mathrm{~kg} \mathrm{ha}^{-1} \mathrm{yr}^{-1}$ at Lahoma. Each year, ammonium nitrate (34-0-0) has been applied broadcast and preplant incorporated at both sites. Phosphorus and potassium as triple superphosphate (0-46-0) and potassium chloride (0-0-62) were applied with nitrogen each year at rates of 29 and $20 \mathrm{~kg} \mathrm{Pha}^{-1}$ and 38 and $56 \mathrm{~kg} \mathrm{Kha}^{-1}$ at experiment 222 and 502 , respectively. Initial soil test data taken from the check plots is shown in Table 1. Each year, forage was hand-harvested from plots at Feekes growth stage 5 (leaf sheath strongly erected) and again at Feekes growth stage 10.5 (flowering complete to top of ear). ${ }^{[14]}$ Grain was harvested from the center of each plot with a Massey Ferguson self-propelled combine. Forage and grain samples were dried and ground to pass a 140 mesh $(106 \mu \mathrm{m})$ sieve and lab analysis was completed for both crop years. Forage samples were extracted with $0.01 \mathrm{M}$ calcium sulfate, and $\mathrm{NH}_{4}-\mathrm{N}$ and $\mathrm{NO}_{3}-\mathrm{N}$ in the extracts was analyzed using flow injection analysis. Each year, forage, straw, and grain samples were analyzed for total $\mathrm{N}$ content via dry combustion analysis using a Carlo Erba NA 1500 analyzer. ${ }^{[15]}$ Total N uptake in the forage, grain, and straw was calculated as the $\% \mathrm{~N}$ contained in each, times the dry matter yield. Plant $\mathrm{N}$ loss was calculated as the difference in the total $\mathrm{N}$ uptake in the Feekes 10.5 forage and the total $\mathrm{N}$ uptake in the grain plus straw. Statistical analysis was performed using SAS. 
Table 1. Surface Soil $(0-15 \mathrm{~cm})$ Chemical Characteristics and Classification at Stillwater (Experiment 222) and Lahoma (Experiment 502), OK, 1998

\begin{tabular}{|c|c|c|c|c|c|c|c|}
\hline \multirow[b]{2}{*}{ Location } & \multirow[b]{2}{*}{$\mathrm{pH}^{\mathrm{a}}$} & $\mathrm{NH}_{4}-\mathrm{N}$ & $\mathrm{NO}_{3}-\mathrm{N}$ & $\mathrm{P}^{\mathrm{b}}$ & $\mathrm{K}^{\mathrm{b}}$ & Total $\mathrm{N}^{\mathrm{c}}$ & Organic $\mathrm{C}^{\mathrm{c}}$ \\
\hline & & \multicolumn{4}{|c|}{$\mathrm{mg} \mathrm{kg}^{-1}$} & \multicolumn{2}{|c|}{$\mathrm{g} \mathrm{kg}^{-1}$} \\
\hline Stillwater & 5.7 & 4.64 & 2.3 & 33 & 159 & 0.9 & 10.6 \\
\hline \multicolumn{8}{|c|}{ Classification: Kirkland silt loam (fine-mixed, thermic Udertic Paleustoll) } \\
\hline Lahoma & 5.6 & 5.6 & 4.0 & 77 & 467 & 0.9 & 11.0 \\
\hline \multicolumn{8}{|c|}{ Classification: Grant silt loam (fine-silty, thermic Udic Argiustoll) } \\
\hline
\end{tabular}

ap: $1: 1$ soil : water.

${ }^{\mathrm{b}} \mathrm{P}$ and $\mathrm{K}$ : Mehlich III.

${ }^{\mathrm{c} O r g a n i c} \mathrm{C}$ and Total N: dry combustion.

\section{RESULTS AND DISCUSSION}

Analysis of variance and associated treatment means for grain and straw yield are reported in Tables 2-5 for experiment 222 and experiment 502 for 1997-98 and 1998-99. Grain yield showed a significant response to increasing N rate at both sites in both years. Similarly, straw yield increased significantly with applied $\mathrm{N}$ at each location and each year, excluding experiment 222 in 1999.

Table 2. Analysis of Variance and Treatment Means for Grain and Straw Yield, Lahoma, OK, 1998

\begin{tabular}{lrrr}
\hline Source of Variation & df & Grain Yield & Straw Yield \\
\hline & & \multicolumn{2}{c}{ Mean Squares, $\mathrm{kg} \mathrm{ha}^{-1}$} \\
Replication & 3 & 793672 & 648246 \\
N rate & 4 & 3047702 & 202730 \\
Residual error & 12 & 588376 & 530556 \\
SED & & 542 & 515 \\
CV & 22 & 63 \\
N rate $\mathrm{kg} \mathrm{ha}^{-1}$ & & $\mathrm{~kg} \mathrm{ha}^{-1}$ & \\
0 & & 2111 & 539 \\
45 & & 3585 & 1546 \\
67 & 3665 & 1197 \\
90 & 3426 & 215 \\
112 & 4541 & 2264 \\
\hline
\end{tabular}

SED: standard error of the difference between two equally replicated means. $\mathrm{CV}$ : coefficient of variation, $\%$. 
Table 3. Analysis of Variance and Treatment Means for Grain and Straw Yield, Lahoma, OK, 1999

\begin{tabular}{lrrr}
\hline Source of Variation & df & Grain Yield & Straw Yield \\
\hline & & \multicolumn{2}{c}{ Mean Squares, $\mathrm{kg} \mathrm{ha}^{-1}$} \\
Replication & 3 & 837542 & 1291289 \\
N rate & 4 & 9079732 & 2142045 \\
Residual error & 12 & 1192464 & 572796 \\
SED & & 772 & 535 \\
CV & 28 & 47 \\
N rate $\mathrm{kg} \mathrm{ha}^{-1}$ & \multicolumn{2}{c}{$\mathrm{kg} \mathrm{ha}^{-1}$} \\
$\quad 0$ & 2181 & 776 \\
45 & 2381 & 1320 \\
67 & 4496 & 1526 \\
90 & 5240 & 1646 \\
112 & & 5191 & 2774 \\
\hline
\end{tabular}

SED: standard error of the difference between two equally replicated means.

$\mathrm{CV}$ : coefficient of variation, $\%$.

Table 4. Analysis of Variance and Treatment Means for Grain and Straw Yield, Stillwater, OK, 1998

\begin{tabular}{|c|c|c|c|}
\hline Source of Variation & df & Grain Yield & Straw Yield \\
\hline & & \multicolumn{2}{|c|}{ Mean Squares, $\mathrm{kg} \mathrm{ha}^{-1}$} \\
\hline Replication & 3 & 186953 & 305468 \\
\hline $\mathrm{N}$ rate & 3 & 20234 & 2757312 \\
\hline Residual error & 9 & 80974 & 269533 \\
\hline SED & & 201 & 367 \\
\hline $\mathrm{CV}$ & & 20 & 29 \\
\hline $\mathrm{N}$ rate $\mathrm{kg} \mathrm{ha}^{-1}$ & & \multicolumn{2}{|c|}{$\mathrm{kg} \mathrm{ha}^{-1}$} \\
\hline 0 & & 983 & 587 \\
\hline 45 & & 1461 & 2029 \\
\hline 90 & & 1594 & 2261 \\
\hline 134 & & 1726 & 2375 \\
\hline
\end{tabular}

SED: standard error of the difference between two equally replicated means.

$\mathrm{CV}$ : coefficient of variation, $\%$. 
Table 5. Analysis of Variance and Treatment Means for Grain and Straw Yield, Stillwater, OK, 1999

\begin{tabular}{|c|c|c|c|}
\hline Source of Variation & df & Grain Yield & Straw Yield \\
\hline & \multicolumn{3}{|c|}{ Mean Squares, $\mathrm{kg} \mathrm{ha}^{-1}$} \\
\hline Replication & 3 & 144881 & 374323 \\
\hline $\mathrm{N}$ rate & 3 & 2196434 & 131411 \\
\hline Residual error & 9 & 377707 & 138575 \\
\hline SED & & 435 & 263 \\
\hline $\mathrm{CV}$ & & 31 & 69 \\
\hline $\mathrm{N}$ rate $\mathrm{kg} \mathrm{ha}^{-1}$ & \multicolumn{3}{|c|}{$\mathrm{kg} \mathrm{ha}^{-1}$} \\
\hline 0 & & 1315 & 273 \\
\hline 45 & & 1529 & 606 \\
\hline 67 & & 2124 & 608 \\
\hline 90 & & 2970 & 675 \\
\hline
\end{tabular}

SED: standard error of the difference between two equally replicated means.

$\mathrm{CV}$ : coefficient of variation, $\%$.

With few exceptions, no measurement of tissue $\mathrm{N}\left(\mathrm{NH}_{4}-\mathrm{N}, \mathrm{NO}_{3}-\mathrm{N}\right.$ and total $\mathrm{N}$ ) was well correlated with estimated plant $\mathrm{N}$ loss. Since estimated plant $\mathrm{N}$ loss is calculated as the total $\mathrm{N}$ uptake in the tissue at flowering minus the total $\mathrm{N}$ uptake at maturity (grain + straw), it is likely that significant amounts of $\mathrm{N}$ were assimilated after flowering in these experiments, since limited $\mathrm{N}$ loss was observed. The increased uptake of $\mathrm{N}$ after anthesis could be a direct result of highly favorable environmental conditions during grain fill. In both years, moisture levels were adequate and temperatures were cool during the period between Feekes 10.5 and maturity. Because of these conditions, wheat continued to assimilate $\mathrm{N}$ and redistribute it to the grain, thus limiting $\mathrm{N}$ loss observed by others. $^{[6,9,16]}$

The relationship between $\mathrm{NO}_{3}-\mathrm{N}$ content at Feekes 5 and total $\mathrm{N}$ at Feekes five at both locations and both years is reported in Figs. 1 and 2. These two parameters were well correlated as could be expected, since the measurements are at the same stage of growth and the two $\mathrm{N}$ contents are interrelated.

Figures 3 and 4 illustrate the relationship between $\mathrm{NO}_{3}-\mathrm{N}$ content at Feekes 5 and the total $\mathrm{N}$ content of forage at Feekes 10.5. Forage $\mathrm{NO}_{3}-\mathrm{N}$ at Feekes 5 was a good predictor of total $\mathrm{N}$ in the wheat forage at Feekes 10.5, the exception being experiment 222 in 1998. This observation, combined with the ability to predict grain yield and total grain nitrogen, may have further use for precision agriculture, since topdress $\mathrm{N}$ is applied at Feekes 5 . Early work by Raun and Westerman ${ }^{[12]}$ showed that grain yield could be reliably predicted using 


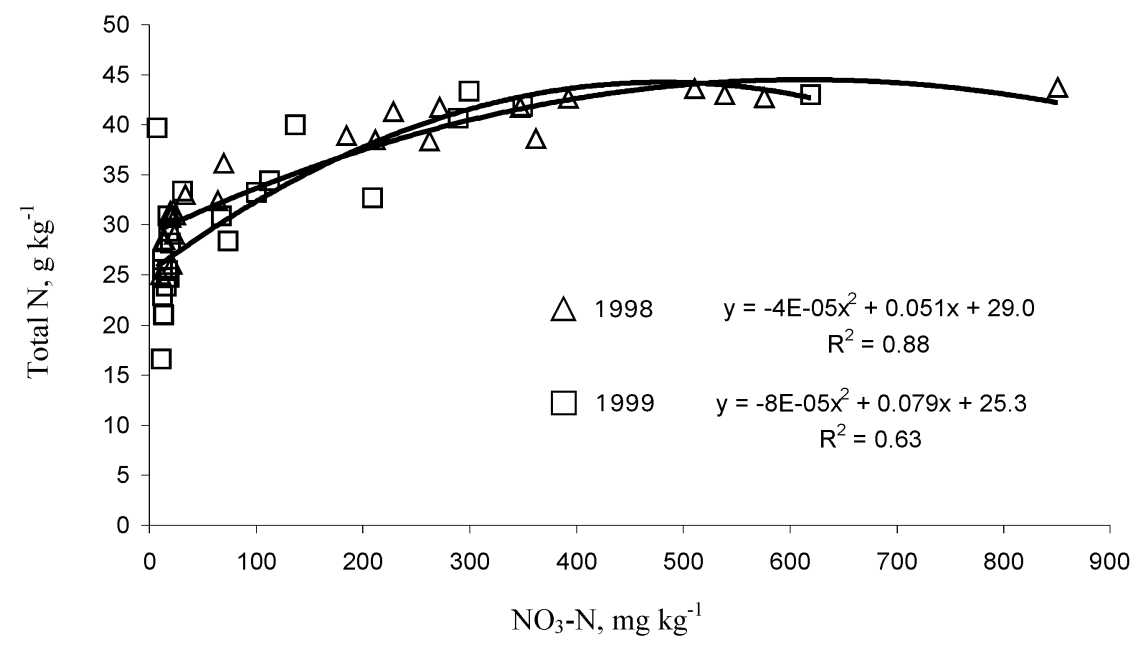

Figure 1. Relationship between $\mathrm{NO}_{3}-\mathrm{N}$ at Feekes 5 and total $\mathrm{N}$ at Feekes 5 at Lahoma 502, 1998 and 1999.

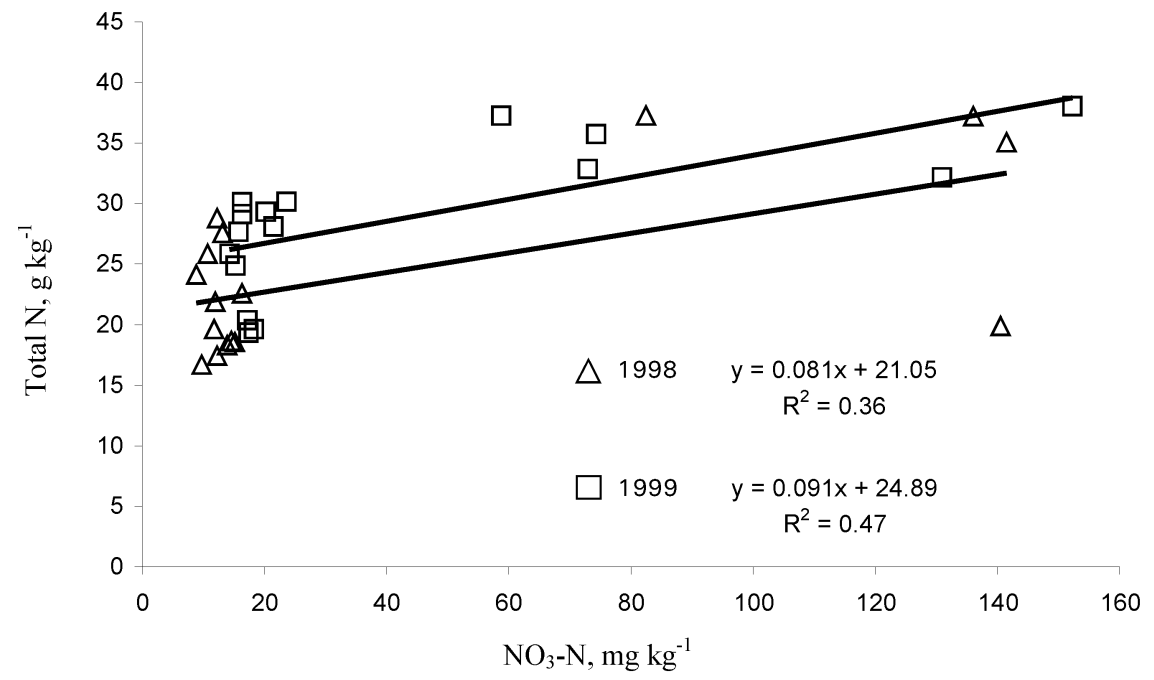

Figure 2. Relationship between $\mathrm{NO}_{3}-\mathrm{N}$ at Feekes 5 and total $\mathrm{N}$ at Feekes 5 at Stillwater 222, 1998 and 1999. 


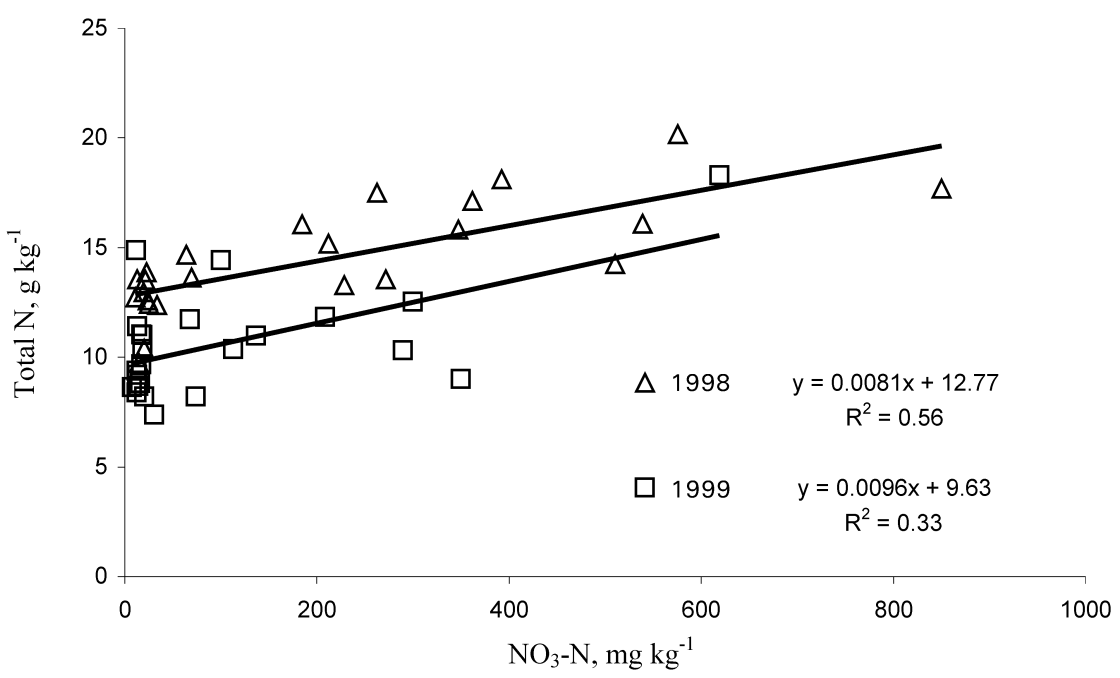

Figure 3. Relationship between $\mathrm{NO}_{3}-\mathrm{N}$ at Feekes $5(x)$ and total $\mathrm{N}$ at Feekes $10.5(y)$ at Lahoma 502, 1998 and 1999.

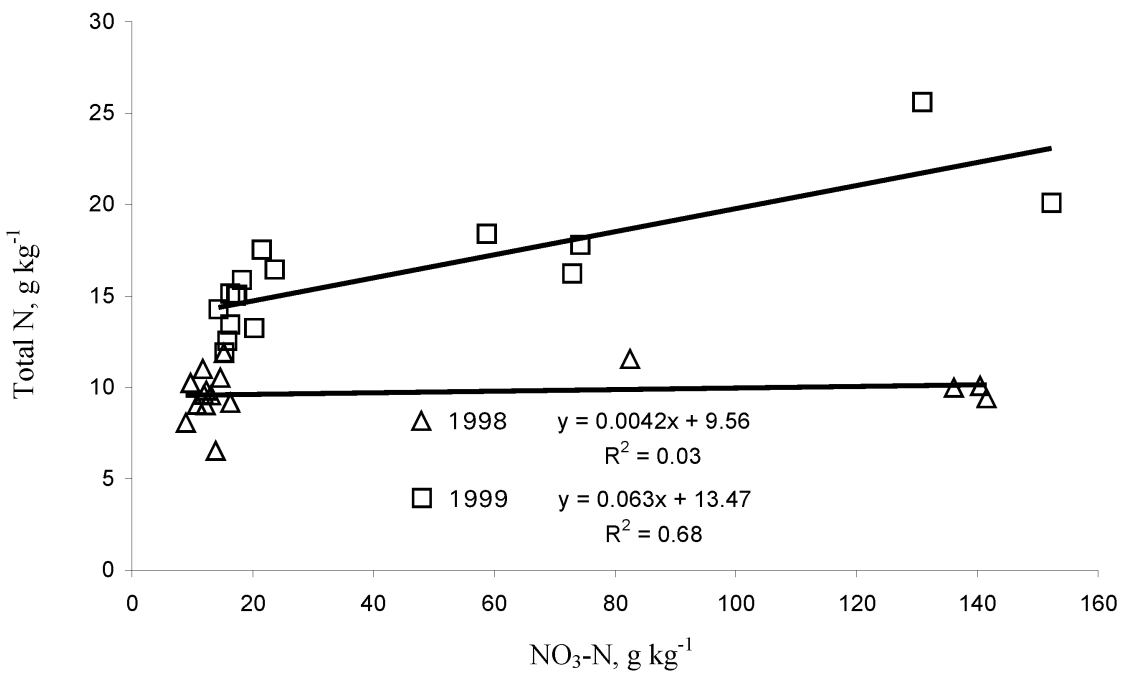

Figure 4. Relationship between $\mathrm{NO}_{3}-\mathrm{N}$ at Feekes $5(x)$ and total $\mathrm{N}$ at Feekes $10.5(y)$ at Stillwater 222, 1998 and 1999. 
$\mathrm{NO}_{3}-\mathrm{N}$ and $\mathrm{PO}_{4}-\mathrm{P}$ in the leaves at Feekes 5. However, they noted that this was highly dependent upon environment. Considering new technologies designed to sense plant health at early stages of growth using sensor-based methods, this information could be interlaced within precision agriculture strategies for midseason nutrient adjustment.

The relationship between $\mathrm{NO}_{3}-\mathrm{N}$ content at Feekes 5 and final grain $\mathrm{N}$ content was also significantly correlated at experiment 502 in both years (Fig. 5), but not at experiment 222. It was interesting to note that total grain $\mathrm{N}$ could be predicted using a forage $\mathrm{NO}_{3}-\mathrm{N}$ reading approximately 2-3 months before the grain was harvested at experiment 502 .

The relationship between total $\mathrm{N}$ Feekes 5 and grain yield at both locations and both years is reported in Figs. 6 and 7. Total $\mathrm{N}$ content of the forage at Feekes 5 was significantly correlated with grain yield. This was the most consistent predictor of grain yield above all other measurements of $\mathrm{N}\left(\mathrm{NH}_{4}-\mathrm{N}\right.$ and/or $\mathrm{NO}_{3}-\mathrm{N}$ ) versus grain yield at either location or in either year. However, it should be noted that similar to the work reported by Raun and Westerman, ${ }^{[12]}$ forage $\mathrm{NO}_{3}-\mathrm{N}$ at Feekes 5 was a relatively good predictor of grain yield in 1998 $\left(R^{2}=0.46,0.55\right)$ but not in $1999\left(R^{2}=0.14,0.17\right)$ at experiments 222 and 502, respectively. Raun and Westerman ${ }^{[12]}$ reported improved correlation of plant $\mathrm{NO}_{3}-\mathrm{N}$ with yield in one year when winter moisture was limiting, and no relationship between plant $\mathrm{NO}_{3}-\mathrm{N}$ in a year when moisture was non-limiting. In

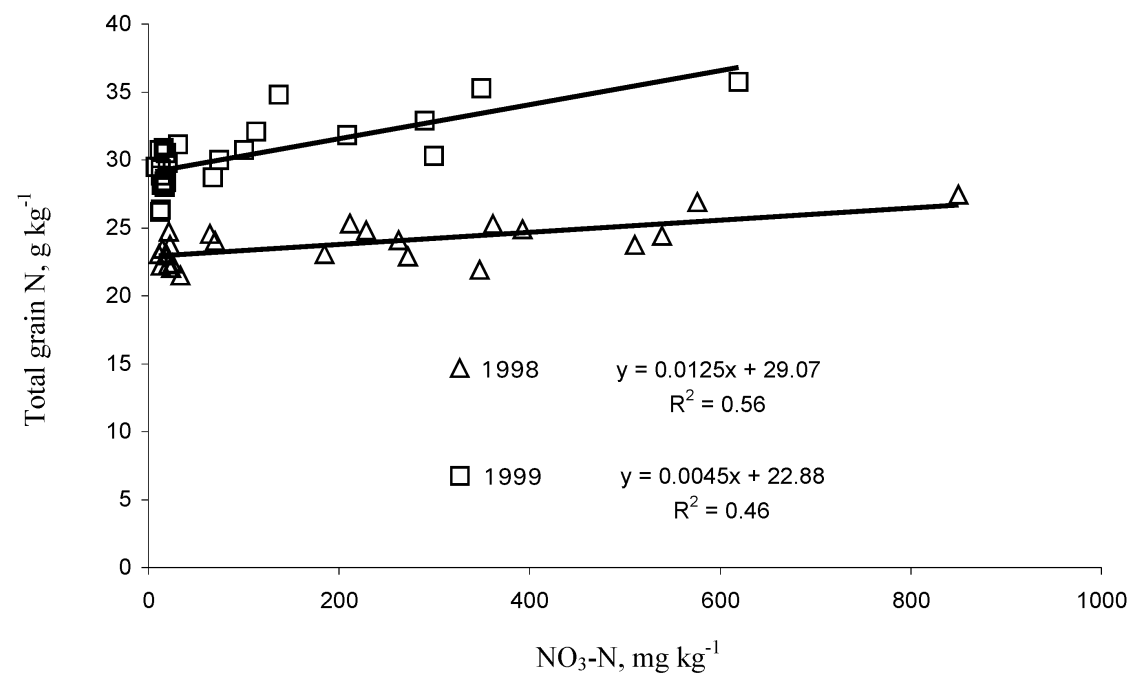

Figure 5. Relationship between $\mathrm{NO}_{3}-\mathrm{N}$ at Feekes 5 and total grain $\mathrm{N}$ at Lahoma 502, 1998 and 1999. 


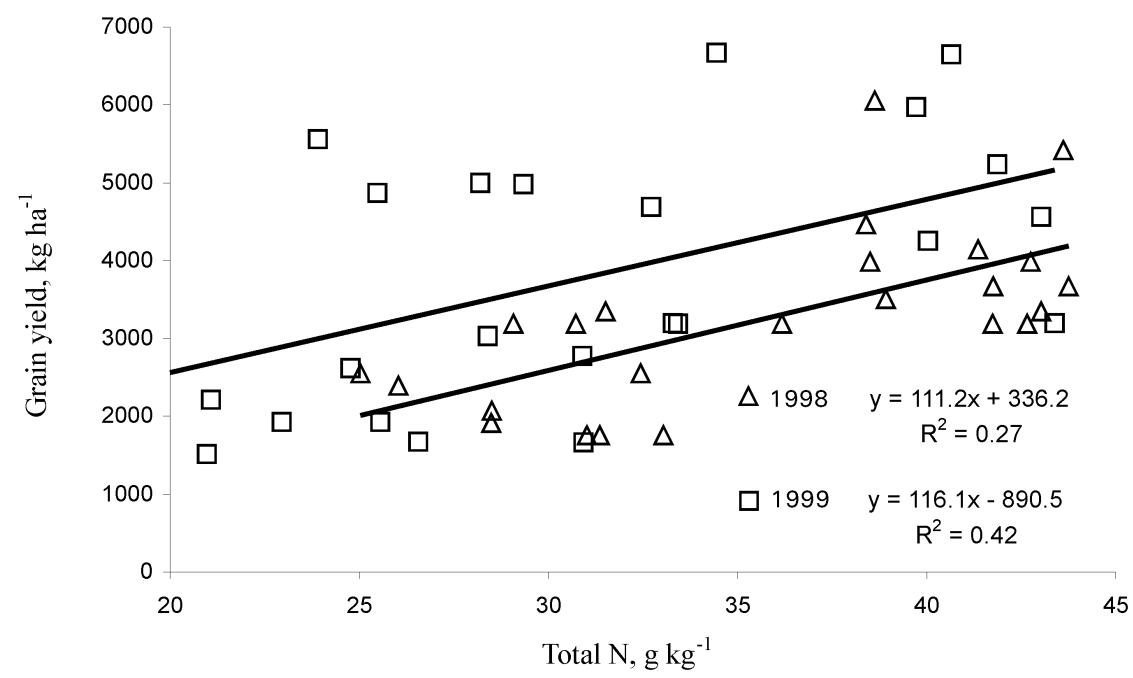

Figure 6. Relationship between total $\mathrm{N}$ at Feekes 5 and grain yield at Lahoma 502, 1998 and 1999.

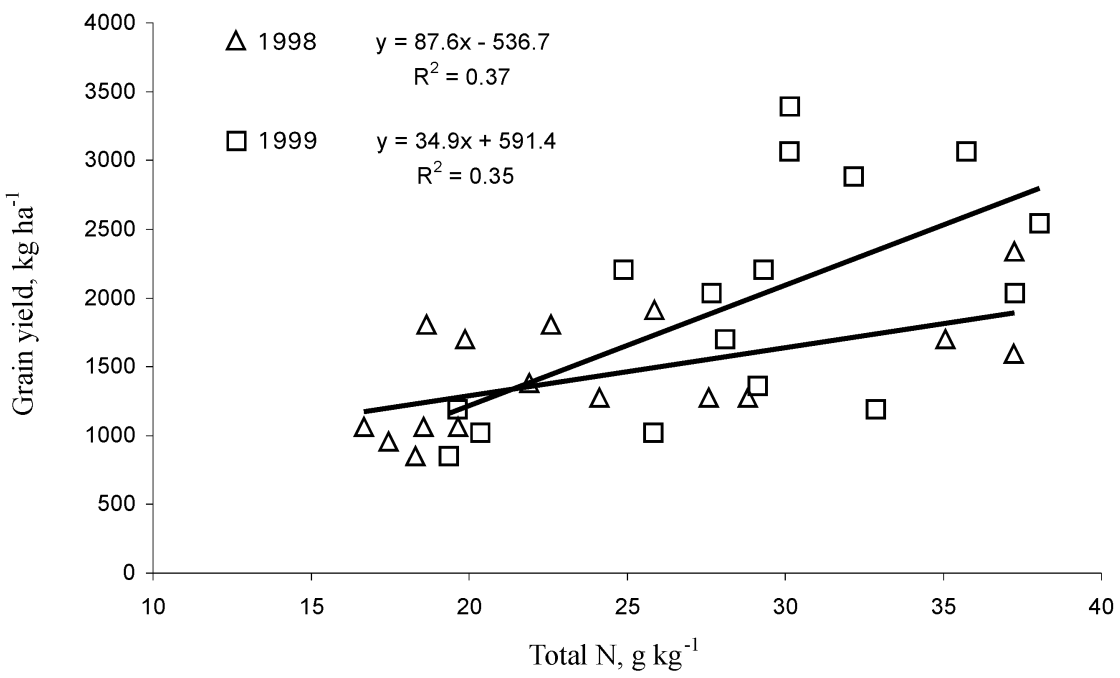

Figure 7. Relationship between total $\mathrm{N}$ at Feekes 5 and grain yield at Stillwater 222, 1998 and 1999. 
Table 6. Total $\mathrm{N}$ and Nitrate- $\mathrm{N}$ in Forage at Feekes 5 and 10.5 at Stillwater and Lahoma in 1998 and 1999

\begin{tabular}{|c|c|c|c|c|}
\hline \multirow[b]{3}{*}{ N Measure } & \multicolumn{4}{|c|}{ Location } \\
\hline & \multicolumn{2}{|c|}{ Stillwater 222} & \multicolumn{2}{|c|}{ Lahoma 502} \\
\hline & 1998 & 1999 & 1998 & 1999 \\
\hline & \multicolumn{4}{|c|}{ Feekes 5} \\
\hline Total $\mathrm{Ng} \mathrm{kg}^{-1}$, average & 24.3 & 28.8 & 35.8 & 30.8 \\
\hline Range (min, max) & $16.7,37.2$ & $19.4,38.0$ & $25.1,43.7$ & $16.6,43.4$ \\
\hline $\mathrm{NO}_{3}-\mathrm{N} \mathrm{mg} \mathrm{kg}^{-1}$, average & 40.7 & 42.8 & 211.4 & 103.2 \\
\hline \multirow[t]{2}{*}{ Range (min, max) } & $8.8,141.5$ & $14.3,152.2$ & $10.5,850.2$ & $7.3,618.9$ \\
\hline & \multicolumn{4}{|c|}{ Feekes 10.5} \\
\hline Total $\mathrm{Ng} \mathrm{kg}^{-1}$, average & 9.7 & 16.2 & 14.5 & 10.6 \\
\hline Range (min, $\max )$ & $6.5,11.9$ & $11.9,25.6$ & $9.8,20.2$ & $7.4,18.3$ \\
\hline $\mathrm{NO}_{3}-\mathrm{N} \mathrm{mg} \mathrm{kg}^{-1}$, average & 10.6 & 64.0 & 70.2 & 55.0 \\
\hline Range (min, $\max )$ & $3.6,38.7$ & $8.1,538.5$ & $5.8,367.9$ & $7.5,833.7$ \\
\hline
\end{tabular}

this work, good stands were achieved in both years, due to adequate fall moisture, however, in 1998, mid-winter conditions were cool, and moisture stress was encountered. Alternatively, 1999 was characterized by a rather mild, wet winter. The environmental conditions in 1998 were consistent with that reported by others who noted a significant relationship between early-season tissue $\mathrm{NO}_{3}-\mathrm{N}$ and grain yield (moisture stress mid-season).

Mean $\mathrm{NO}_{3}-\mathrm{N}$ and total $\mathrm{N}$ levels in wheat forage at Feekes 5 and 10.5 are reported for both locations in 1998 and 1999 (Table 6). The mean and range in $\mathrm{NO}_{3}-\mathrm{N}$ and total $\mathrm{N}$ in wheat forage tended to be greater in 1998 at Feekes 5 when compared to 1999, suggesting increased $\mathrm{N}$ accumulation during stress years noted by Raun and Westerman. ${ }^{[12]}$

\section{CONCLUSIONS}

Concentrations of $\mathrm{NH}_{4}-\mathrm{N}$ and $\mathrm{NO}_{3}-\mathrm{N}$, and total $\mathrm{N}$ contents in wheat tissue at Feekes 5 and Feekes 10.5 were not good predictors of estimated N loss. Ideal climatic conditions during the period from anthesis to maturity may have minimized $\mathrm{N}$ losses. These conditions may have promoted further $\mathrm{N}$ uptake from anthesis, thus increasing the error associated with estimated plant $\mathrm{N}$ loss. 
The use of early season $\mathrm{N}$ measurements may prove to be effective estimates of late-season $\mathrm{N}$ accumulation in wheat. Nitrate- $\mathrm{N}$ contents at Feekes 5 were significantly correlated with total $\mathrm{N}$ contents of the forage at Feekes 5, however the relationship was not as good as expected. Nitrate- $\mathrm{N}$ content at Feekes five was significantly correlated with total $\mathrm{N}$ content at Feekes 10.5. At Lahoma 502, Feekes $5 \mathrm{NO}_{3}-\mathrm{N}$ contents were significantly correlated with grain $\mathrm{N}$. This relationship was not observed at Stillwater 222 in either year. Total $\mathrm{N}$ in the forage at Feekes five was significantly correlated with grain yield at both sites in both years.

\section{REFERENCES}

1. Aulakh, M.S.; Rennie, D.A.; Paul, E.A. Gasoues Nitrogen Losses from Cropped and Summer Fallowed Soils. Can. J. Soil Sci. 1982, 62, 187-195.

2. Hilton, B.R.; Fixen, P.E.; Woodward, H.J. Effects of Tillage, Nitrogen Placement, and Wheel Compaction on Denitrification Rates in the Corn Cycle of a Corn-Oats Rotation. J. Plant Nutr. 1994, 17, 1341-1357.

3. Al-Kanani, T.; Mackenzie, A.F.; Blenkhorn, J. The Influence of Formula Modifications on Ammonia Losses from Surfaced-Applied Urea-Ammonium Nitrate Solutions. Fert. Res. 1990, 22, 49-59.

4. Volk, G.M. Efficiency of Fertilizer Urea as Affected by Method of Application, Soil Moisture, and Lime. Agron. J. 1966, 58, 249-252.

5. Robbins, C.W.; Carter, D.L. Nitrate-Nitrogen Leached Below the Root Zone During and Following Alfalfa. J. Environ. Qual. 1980, 9, 447-450.

6. Harper, L.A.; Sharpe, R.R.; Langdale, G.W.; Giddens, J.E. Nitrogen Cycling in a Wheat Crop: Soil, Plant, and Aerial Nitrogen Transport. Agron. J. 1987, 79, 965-973.

7. Francis, D.D.; Schepers, J.S.; Vigil, M.F. Post-anthesis Nitrogen Loss from Corn. Agron. J. 1993, 85, 659-663.

8. Papakosta, D.K.; Gagianas, A.A. Nitrogen Accumulation, Remobilization, and Losses for Mediterranean Wheat During Grain Filling. Agron. J. 1991, 83, 864-870.

9. Daigger, L.A.; Sander, D.H.; Peterson, G.A. Nitrogen Content of Winter Wheat During Growth and Naturation. Agron. J. 1976, 68, 815-818.

10. Silberbuh, M.; Lips, S.H. Potassium, Nitrogen, Ammonium/Nitrate Ratio, and Sodium Chloride Effects on Wheat Growth. II. Tillering and Grain Yield. J. Plant Nutr. 1992, 14, 765-773.

11. Martin del Molino, I.M. Relationship Between Wheat Grain Protein Yield and Grain Yield, Plant Growth, and Nutrition at Anthesis. Plant Physiol. 1991, 14, 1297-1306. 
12. Raun, W.R.; Westerman, R.L. Nitrate-N and Phosphate-P Concentrations in Winter Wheat at Varying Growth Stages. J. Plant Nutr. 1991, 14, 267281.

13. Gregory, P.J.; Marshall, B.; Biscoe, P.V. Nutrient Relations in Winter Wheat. (3) Nitrogen Uptake, Photosynthesis of Flag Leaves and Translocation of Nitrogen to Grain. Agric. Sci. 1981, 96, 539-547.

14. Large, E.C. Growth Stages in Cereals. Plant Pathol. 1954, 3, 128-129.

15. Schepers, J.S.; Francis, D.D.; Thompson, M.T. Simultaneous Determination of Total C, Total N, and ${ }^{15} \mathrm{~N}$ on Soil and Plant Material. Commun. Soil Sci. Plant Anal. 1989, 20, 949-959.

16. Kanampiu, F.K.; Raun, W.R.; Johnson, G.V. Effect of Nitrogen Rate on Plant Nitrogen Loss in Winter Wheat Varieties. J. Plant Nutr. 1997, 20, 389-404. 